\title{
Cardiac Biomarkers in hypertensive disorders of pregnancy
}

\author{
Dolina Gencheva ${ }^{1,2 *}$, Fedya Nikolov ${ }^{1,2}$, Ekaterina Uchikova ${ }^{3,4}$, Krasimira Hristova $^{5}$, Rosen Mihaylov $^{6,7}$, Blagovesta Pencheva ${ }^{6}$ \\ ${ }^{1}$ Department of Internal Diseases, Section of Cardiology, Medical University - Plovdiv, Plovdiv, Bulgaria; ${ }^{2}$ Clinic of Cardiology, \\ UMHAT "Sveti Georgi" Plovdiv, Plovdiv, Bulgaria; ${ }^{3}$ Department of Obstetrics and Gynaecology, Medical University - Plovdiv, \\ Plovdiv, Bulgaria; ${ }^{4}$ Clinic of Obstetrics and Gynaecology, UMHAT "Sveti Georgi" Plovdiv, Plovdiv, Bulgaria; ${ }^{5}$ Department of \\ Cardiology, MHAT for women's Health "Nadezhda", Sofia, Bulgaria; 'Independent Medical Diagnostic Laboratory "RAMUS", \\ Sofia, Bulgaria; ${ }^{7}$ Medical College "Jordanka Filaretova”, Sofia, Bulgaria
}

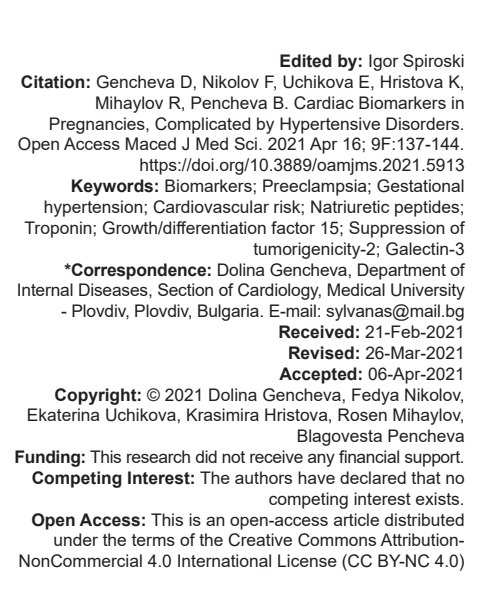

\section{Introduction}

Both cardiovascular diseases [1] and hypertensive disorders of pregnancy [2] are socially important entities leading to a considerable disability and mortality in people of active ages. The mechanisms for the development of hypertensive disorders of pregnancy are not completely understood, despite the considerable progress in the field. Poor placentation [3] is now believed to be the triggering event that results in a multisystemic response from the mother that can lead to devastating consequences, such as HELLP syndrome (hemolysis, elevated liver enzymes, and low platelets syndrome), pulmonary edema, renal failure, encephalopathy, eclampsia, disseminated intravascular coagulation, and others [4]. The pregnancy itself is at risk as fetal growth is deterred and premature birth, abruption of the placenta and fetal death are more likely to happen [5]. Although hypertensive disorders induced by pregnancy resolve with the delivery of the placenta or soon after, it is now known that the risk of numerous cardiovascular diseases - arterial hypertension, coronary atherosclerosis, stroke, heart failure, peripheral artery disease, and venous thromboembolism [6], [7] remains higher in those women years after the completion of the pregnancy and even lead to a higher cardiovascular mortality [8]. A very plausible theory - that of hypertensive disorders of pregnancy being a "stress test" [9] unmasking latent endothelial dysfunction and the higher risk for future occurrence of cardiovascular diseases in women, unifies those seemingly different pathologies. Reports of more pronounced changes in the structure and the function of the heart during such pregnancies are not uncommon, such as an increase of the left ventricular mass, dilation of chambers, features of diastolic dysfunction, and occasionally of systolic dysfunction [10].

Indeed, hypertensive disorders of pregnancy share some common pathophysiological mechanisms with cardiovascular diseases as well as risk factors. Preeclampsia is characterized by vasoconstriction and increases in the afterload as a result of a imbalance between vasodilators and vasoconstrictors - there is an increased sensitivity to angiotensin II and less production of nitric oxide [11]. A similar imbalance has been implicated in the mediation of chronic heart failure - the end stage of all severe cardiovascular diseases, where it leads to progressive remodeling and cardiac dysfunction 
[12]. Oxidative stress and endothelial dysfunction are also common denominators between those groups of diseases [13]. In hypertensive disorders of pregnancy, there is an exaggerated activation of inflammation as evidenced by the presence of elevated levels of proinflammatory cytokines [14] and low-grade inflammation is also known to accelerate the progression of atherosclerosis and is connected to poor cardiovascular outcomes [15]. Hypertensive disorders of pregnancy are also associated with an unfavorable lipid profile [16] and with insulin resistance [17] - both of which are risk factors for the development of cardiovascular diseases. Besides the obstetric risk factors, hypertensive disorders of pregnancy are more common in women presenting with typical cardiovascular risk factors, such as obesity, diabetes, pre-existing arterial hypertension, and thrombophilias [18].

Modern-day cardiology makes use of biomarkers, both in acute and chronic situations, as they provide additional information on mechanisms of disease development, facilitate treatment, and define prognosis. The abovementioned poses the question of whether cardiac biomarkers could also be applied successfully in the assessment of women during hypertensive pregnancies. Proper characterization of women during this natural "stress test" could allow for a better understanding of the function of the heart and the vascular system, and therefore provide a more precise risk stratification.

In this review, we aim to summarize the existing evidence of the presence of adverse cardiac biomarker profile in women during or after a hypertensive pregnancy when compared to normotensive pregnancies, and if available to provide information on correlations between the levels of those biomarkers and the clinicopathological characteristics of the women. We have included the following biomarkers - natriuretic peptides, highsensitivity cardiac troponins, growth/differentiation factor 15 (GDF15), the suppression of tumorigenicity-2 (ST2), and galectin-3. Biomarkers with a primary role in the development of preeclampsia such as placental growth factor (PIGF), soluble FMS-like tyrosine kinase 1 (sFIt-1), and vascular endothelial growth factor (VEGF) are not an object of this review, although they are known to have certain uses in the field of cardiology.

\section{Natriuretic peptides (BNP and NT-proBNP)}

The family of natriuretic peptides consists of A-, B-, and C-type natriuretic peptides. The prohormone proBNP is secreted mostly by the ventricular cardiomyocytes as a response to the stretching of the myocardial wall due to elevated pressures and then its molecule is halved into the biologically active BNP and the inactive NT-proBNP. BNP stimulates diuresis, natriuresis, and vascular vasodilation and antagonizes the two systems mediating heart failure the renin-angiotensin-aldosterone system and the sympathetic nervous system [19]. The use of either
BNP or NT-proBNP is recommended by the current heart failure documents of the American College of Cardiology Foundation (ACCF) and the American Heart Association (AHA) for peptides for establishing the diagnosis of heart failure in patients with dyspnea, as well as for prognostic purposes in chronic and acutely decompensated cases with the highest class of recommendation I and level of evidence A. With a lower strength of recommendation and evidence, they can be used for post-discharge prognosis in chronic heart failure and in patients at risk of developing heart failure (IIA, B-N and IIA, B-NR) [20]. It is also worth noting that BNP/NT-proBNP is so far the only biomarkers recommended by the European Society of Cardiology in the setting of heart failure [21]

Higher levels of NT-proBNP and BNP also correlate with a higher all-cause mortality in heart failure patients with preserved and reduced ejection fraction in the 6 months after hospital discharge [22]. BNP is also known to correlate with the degree of the left ventricular diastolic dysfunction, right ventricular systolic dysfunction [23], and also with a larger left ventricular end-systolic and end-diastolic diameter, left atrial diameter, and the degree of mitral insufficiency and lower left ventricular ejection fraction in the setting of acute heart failure, as measured echocardiographically [24]. In a study by Tschöpe et al., the levels of NT-proBNP correlated with invasively measured parameters of diastolic dysfunction - left ventricle end-diastolic pressure, dP/dt, Tau, and Pulmonary capillary wedge pressure rest and during exercise; as well as with the NYHA functional class of heart failure [25].

\section{In hypertensive disorders of pregnancy}

Elevated levels of natriuretic peptides in hypertensive diseases of pregnancy could be a defense mechanism directed against vasoconstriction, known to happen in those conditions. In a systematic review, Afshani et al. [26] selected 12 studies that examined the relationship between BNP levels and preeclampsia, eclampsia, and preterm delivery. The data suggested that levels of BNP remained unaltered in normal pregnancy, but were elevated in the third trimester of preeclamptic women and remained so 3-6 months after the end of the pregnancy. The authors stated that high levels of BNP could be an indicator of cardiovascular complications and preterm delivery, but more investigation on the topic is needed. There was no association between natriuretic peptides and HELLP syndrome and no association with the progression to eclampsia.

Another meta-analysis [27], incorporating data from three studies about BNP, concluded that BNP levels were also elevated when comparing severe to mild forms of preeclampsia. A different study discovered higher levels of BNP in early-onset preeclampsia compared to late-onset preeclampsia [28]. Few studies 
exist that directly examine the association between the levels of natriuretic peptides and echocardiographic findings in hypertensive pregnancies. A study by Naidoo et al. additionally to the increased pre-delivery value of NT-proBNP in preeclamptic women discovered weak positive correlations between NT-proBNP and the tissue Doppler Ea of the mother and the resistance index of the umbilical artery [29]. The serum BNP correlated negatively with ejection fraction and TAPSE and positively with $\mathrm{E} / \mathrm{Em}$ ratio in the severe preeclampsia group of a 2019 study, but the levels themselves were not increased after adjustment for maternal and gestational age when severe preeclampsia was compared to the controls [30]. Tihtonen et al. found a positive correlation between NT-proBNP and systemic vascular resistance index and an inverse one with the cardiac index in preeclamptic women as assessed by whole-body impedance cardiography [31].

As far as gestational hypertension is concerned, in 2016, Sadlecki et al. reported that serum NT-proBNP and BMI were independent predictors for the occurrence of gestational hypertension in multivariate logistic regression analysis. They were also indicative for the presence of preeclampsia and correlated inversely with birth weight. The authors suggested the use of NT-proBNP for a better identification and management of such women; however, one limitation of the study was the small sample size (14 women with $\mathrm{PE}$ and 26 with $\mathrm{GH}$ ) [32].

\section{Cardiac troponins}

Troponin I and troponin $\mathrm{T}$ are muscle proteins that regulate muscle contraction and are highly specific and sensitive for the detection of myocardial injury. Elevated troponin I or T levels are a necessary criterion for the establishment of the diagnosis of myocardial infarction as per the fourth universal definition of myocardial infarction [33] and high-sensitivity assays are useful for the rule-out of myocardial injury in the acute clinical setting. Higher levels are also known to correlate to the size of the myocardial infarction and to predict worse outcomes in acute coronary syndromes [34].

High-sensitivity cardiac troponins are associated with the incidence of coronary heart disease, fatal coronary heart disease, total mortality, and heart failure [35]. The 2017 update of the ACC/ AHA/HFSA heart failure guideline recommends the use of high-sensitivity cardiac troponin as a marker of cardiac fibrosis for the prediction of hospitalization and death in heart failure patients, although with a lower class and evidence of recommendation (IIB, B-NR), when compared to the natriuretic peptides [20].

\section{In hypertensive disorders of pregnancy}

There are conflicting reports on whether hypertensive pregnancies lead to higher levels of cardiac troponins or not. A systematic review of nine studies of up to 2015 involving 719 women, found that five of the studies indicated significantly higher levels of troponin I in preeclampsia, but the other four did not; and additionally, the authors of the review criticized the lack of consecutive measurements [36]. Fleming et al. found higher levels of troponin I in the preeclampsia group compared to the gestational hypertension one in their study [37]. A 2018 study found elevated high-sensitivity troponin I in $25 \%$ of the women with preeclampsia and also a significant linear relationship between troponin and mean arterial pressure [38]. In a relatively large prospective study, high-sensitivity cardiac troponin I was an independent predictor of gestational hypertension and preeclampsia during pregnancy and after delivery - with an odds ratio of 9.3 in unadjusted and 11.5 in adjusted models per doubling of its concentrations [39].

Conversely, the authors of a study that did not confirm elevated troponin I in preeclamptic pregnancies advised the exclusion of other reasons for myocardial injury in women with elevated cardiac troponins [40].

Umazume et al. made serial measurement of high-sensitivity troponin I accompanied by echocardiographic assessment of women with hypertensive disorders of pregnancy and found that the serum levels correlated negatively with the maternal e-wave in the third trimester and 1 month postpartum. The authors found an area under the curve of 0.82 and 0.81 , respectively, for the prediction of reduced left ventricular relaxation in those periods [41]. Muijsers et al. measured high-sensitivity troponin I levels 9-10 years after an early-onset preeclamptic pregnancy and while there was no difference compared to women with a normotensive pregnancy in that time period, currently, hypertensive women with a history of early-onset preeclampsia had higher levels than normotensive women with early-onset preeclampsia. Higher troponin levels were also associated with a higher blood pressure [42].

\section{Soluble suppression of tumorigenicity-2}

\section{(sST2)}

A relatively novel biomarker in the cardiovascular field, the suppression of tumorigenicity-2 (ST2) is a member of the interleukin-1 family, with a circulatory form - soluble ST2 (sST2) that binds to IL-33 and thus promotes inflammation, hypertrophy, fibrosis, and ventricular dysfunction [43]. The biomarker is secreted by the cardiac myocytes and fibroblasts and is increased under mechanical stress [44]. The biomarker has a promising role in the prognosis and management of heart failure [45], Eisenmenger's syndrome [46], and major adverse cardiac events and is also associated with the complexity of coronary atherosclerotic lesions [47].

The current ACC/AHA/HFSA update on the Heart Failure Guideline also recommends its use in 
heart failure as it could provide additional prognostic information and risk stratification to the use of natriuretic peptides with a class of recommendation IIB, B-NR [20]. In a direct comparison study between sST2, galectin-3, and high-sensitivity troponin $\mathrm{T}$ in chronic heart failure patients with reduced ejection fraction, out of the three biomarkers, only the serial measurements of sST2 predicted reserve myocardial modeling and independently added to the risk model for adverse cardiovascular events [48]. In patients with heart failure with preserved ejection fraction, SST2 levels were associated with the presence of diabetes mellitus, atrial fibrillation, systemic congestion, and kidney failure. It also correlated with worse exercise tolerance and higher NT-proBNP levels, C-reactive protein, and highsensitivity troponin [49].

\section{In hypertensive disorders of pregnancy}

Soluble ST2 has also been examined in the setting of preeclampsia, although large studies are not available. In a longitudinal study of 160 uncomplicated pregnancies and 40 preeclamptic ones, maternal plasma sST2 concentrations were elevated 6 weeks before the clinical presentation of preeclampsia, which the authors attributed to an exaggerated inflammatory response or a misbalance between humoral and cellular immunity [50]. Higher concentrations of sST2 were found in women with preeclampsia compared to normotensive pregnancies and the difference was more pronounced in early onset and in severe preeclampsia. There were no correlations with the uterine or umbilical Doppler findings. In addition, there was a negative correlation with the placental growth factor - a pro-angiogenic factor which is necessary for proper placentation and is pathologically reduced in preeclampsia [51]. In a recent, relatively, but small study sST2 levels were elevated in 24 women with severe preeclampsia $24 \mathrm{~h}$ before delivery, but not 1 year afterward, compared to healthy pregnant controls and additionally in the preeclampsia group, there was an inverse correlation with echocardiographic markers of the left ventricular diastolic function, but not with the systolic ones [52].

\section{Galectin-3}

Galectin-3 is a protein with an established role in inflammation, immunity, and oncogenesis. It is secreted by the activated macrophages and its main function is associated with the activation of the fibroblasts that form collagen and fibrotic tissue [53]. Experimental animal studies prove its role in cardiac remodeling as a result of pressure overload [54]. In human studies, its upregulation has been established in patients with the left ventricular hypertrophy [53] and heart failure [55]. Its levels correlated with the number of hospitalizations for heart failure [56] and were also elevated in pulmonary hypertension, where they correlated with the prognosis, regardless of etiology [57]. In a 2016 study, there was a significant correlation between galectin-3 levels and the thickness of the ventricular septum, the left ventricular posterior wall, and the left ventricular mass in arterial hypertension. In the same study, its levels were elevated even in newly diagnosed hypertensive patients [58]. In a non-pregnant population, a negative correlation was discovered between galectin-3 levels and some parameters of the right ventricular function - TAPSE and the tricuspid S-wave, in patients with reduced left ventricular function, but the levels were not associated with the left-sided parameters themselves [59]. The recommendation of its use for additional risk stratification by the ACC/AHA/HFSA in chronic heart failure is IIB, B-NR, similarly to that of high-sensitivity troponin and sST2 [20].

\section{In hypertensive disorders of pregnancy}

Galectin-3 is not much studied in pregnancyinduced hypertension or its complications. However, we managed to identify a couple of relevant studies. In a 2019 study by Taha et al. [60], the Galectin-3 levels were significantly higher in preeclamptic women and additionally indicated a worse lipid profile - they showed a positive correlation with the total, VLDL, LDL cholesterol, and triglycerides and a negative one with HDL cholesterol. A positive correlation was also present with maternal and gestational age of the women. Jeschke et al. [61] found an upregulation of both galectin-1 and galectin-3 in the extravillous trophoblast of eight preeclamptic placentas and five placentas of women with HELLP syndrome when compared to placentas of healthy women. In another study, there was also a higher galectin-3 expression in the umbilical cord of small-for-gestational-age infants when compared to appropriate-for-gestational-age ones [62].

\section{Growth/differentiation factor 15 (GDF15)}

GDF-15 is a protein from the transforming growth factor- $\beta$ superfamily that is normally secreted in small quantities by many organs, but in much higher concentrations from the placenta in pregnancy. It is involved in apoptosis, inflammation, oncogenesis, and the metabolism, but its role in pregnancy is not entirely clear [63]. It is now known to participate in cardiac ischemia [64] and in the formation of the atherosclerotic plaque [65]. High concentrations are present in heart failure and in different forms of coronary artery disease and are related to the progression of the disease, ventricular remodeling, plaque burden, and the severity of ischemia [66]. A large study proved that it can be used in the prediction of all-cause, cardiovascular, and noncardiovascular mortality with better predictive abilities for all-cause mortality than the popular predictors NT-proBNP and the C-reactive protein [67]. 


\section{In hypertensive disorders of pregnancy}

In normal pregnancy, serum levels of GDF-15 were elevated with the progression of the pregnancy, but were reduced in the third trimester in 34 women with preeclampsia, especially if the preeclampsia was late onset. It, however, could not be used as an early prediction (11-13 gestational week), as the levels did not differ in women who later on developed preeclampsia [68]. Results from other studies, however, showed the opposite - higher concentrations in hypertensive pregnancies. Sugulle et al. [69] examined GDF-15 concentrations in preeclampsia to test the hypothesis that the placental oxidative stress is causing elevation of its levels. According to their results, maternal serum GDF-15 concentrations were higher in preeclamptic pregnancies at term compared to controls, and additionally, levels were elevated in the fetal circulation and the amniotic fluid in cases of preeclampsia and superimposed preeclampsia. The placental GDF-15 mRNBA was also elevated in preeclampsia. The authors viewed their finding as a confirmation of the presence of oxidative stress and ischemia in preeclamptic pregnancies. In the same study, the levels were also higher in women with diabetes mellitus. Another group of authors [70] also found significantly elevated concentrations in preeclampsia and the highest levels of GDF-15 were in its early-onset forms. There was a positive correlation with the systolic and diastolic blood pressure and a negative one with the gestational age of delivery and the birth weight. Those results were explained with the production of GDF-15 in the setting of cytokine-mediated endothelial injury.

\section{Conclusion}

The use of cardiac biomarkers in pregnancy is unfortunately not a widely researched area, but a progress in it could lead to a better understanding of the mechanisms behind the development of hypertensive disorders of pregnancy. In addition, research could provide an explanation for the higher cardiovascular risk in affected women both during and years after a hypertensive pregnancy. The growing evidence of cardiac biomarkers being altered during hypertensive pregnancies necessitates a more thorough cardiologic assessment of affected women and could be promising for risk stratification for future cardiovascular events. More pronounced changes in the biomarker levels could indicate a worse cardiovascular profile. The identification of such women can facilitate health-care provision and prophylaxis, therefore improving the management of women's health issues. The information on the topic, however, remains somewhat scarce, especially when correlations of biomarkers with cardiac structural or functional changes are sought after. Larger studies are needed, especially with more information about gestational hypertension as this group of women tends to be underexamined when compared to preeclampsia, while the risk of further cardiovascular complications is far from negligible.

\section{References}

1. Eurostat. Cardiovascular Diseases; 2020. Available from https://www.ec.europa.eu/eurostat/statistics-explained/ index.php/cardiovascular_diseases_statistics\#deaths_from_ cardiovascular_diseases. [Last accessed on 2021 Feb 04]

2. Lo JO, Mission JF, Caughey AB. Hypertensive disease of pregnancy and maternal mortality. Curr Opin Obstet Gynecol. 2013;25(2):124-32. PMid:23403779

3. Roberts JM, Hubel CA. The two stage model of preeclampsia Variations on the theme. Placenta. 2009;30 Suppl A:S32-7. https://doi.org/10.1016/j.placenta.2008.11.009 PMid:19070896

4. Pankiewicz K, Szczerba E, Maciejewski T, Fijałkowska A. Nonobstetric complications in preeclampsia. Prz Menopauzalny. 2019;18(2):99-109. https://doi.org/10.5114/pm.2019.85785 PMid:31485207

5. Khalil G, Hameed A. Preeclampsia: Pathophysiology and the maternal-fetal risk. J Hypertens Manag. 2017;3:024.

6. Lykke JA, Langhoff-Roos J, Sibai BM, Funai EF, Triche EW, Paidas MJ. Hypertensive pregnancy disorders and subsequent cardiovascular morbidity and Type 2 diabetes mellitus in the mother. Hypertension. 2009;53(6):944-51. https://doi. org/10.1161/hypertensionaha.109.130765

PMid:19433776

7. Wu P, Haththotuwa R, Kwok CS, Babu A, Kotronias RA Rushton C, et al. Preeclampsia and future cardiovascular health: A systematic review and meta-analysis. Circ Cardiovasc Qual Outcomes. 2017;10(2):e003497. https://doi.org/10.1161/ circoutcomes.116.003497

PMid:28228456

8. Theilen LH, Fraser A, Hollingshaus MS, Schliep KC Varner MW, Smith KR, et al. All-cause and cause-specific mortality after hypertensive disease of pregnancy. Obstet Gynecol. 2016;128(2):238-44. https://doi.org/10.1097/ aog.0000000000001534

PMid:27400006

9. Craici I, Wagner S, Garovic VD. Preeclampsia and future cardiovascular risk: Formal risk factor or failed stress test? Ther Adv Cardiovasc Dis. 2008;2(4):249-59. https://doi. org/10.1177/1753944708094227

PMid:19124425

10. Choi SK, Shin JC, Park YG, Park IY, Kwon JY, Ko HS, et al. The efficacy of peripartum transthoracic echocardiography in women with preeclampsia. Pregnancy Hypertens. 2017;10:187-91. https://doi.org/10.1016/j.preghy.2017.05.002 PMid:29153677

11. Palei AC, Spradley FT, Warrington JP, George EM, Granger JP. Pathophysiology of hypertension in pre-eclampsia: A lesson in integrative physiology. Acta Physiol (Oxf). 2013;208(3):224-33. https://doi.org/10.1111/apha.12106 PMid:23590594

12. Fenton M, Burch M. Understanding chronic heart failure. Arch 
Dis Child. 2007;92(9):812-6.

PMid: 17715446

13. Sánchez-Aranguren LC, Prada CE, Riaño-Medina CE, Lopez M Endothelial dysfunction and preeclampsia: Role of oxidative stress. Front Physiol. 2014;5:372. https://doi.org/10.3389/ fphys.2014.00372

PMid:25346691

14. Harmon AC, Cornelius DC, Amaral LM, Faulkner JL, Cunningham MW Jr., Wallace K, et al. The role of inflammation in the pathology of preeclampsia. Clin Sci (Lond). 2016;130(6):40919. https://doi.org/10.1042/cs20150702 PMid:26846579

15. Koenig W. Low-grade inflammation modifies cardiovascular risk even at very low LDL-C levels: Are we aiming for a dual target concept? Circulation. 2018;138(2):150-3. https://doi. org/10.1161/circulationaha.118.035107 PMid:29986958

16. Wojcik-Baszko D, Charkiewicz K, Laudanski P. Role of dyslipidemia in preeclampsia-a review of lipidomic analysis of blood, placenta, syncytiotrophoblast microvesicles and umbilical cord artery from women with preeclampsia. Prostaglandins Other Lipid Mediat. 2018;139:19-23. https://doi.org/10.1016/j. prostaglandins.2018.09.006 PMid:30248406

17. Hauth JC, Clifton RG, Roberts JM, Myatt L, Spong CY, Leveno KJ, et al. Maternal insulin resistance and preeclampsia. Am J Obstet Gynecol. 2011;204(4):327.e1-6. PMid:21458622

18. English FA, Kenny LC, McCarthy FP. Risk factors and effective management of preeclampsia. Integr Blood Press Control. 2015;8:7-12.

PMid:25767405

19. Cao Z, Jia Y, Zhu B. BNP and NT-proBNP as diagnostic biomarkers for cardiac dysfunction in both clinical and forensic medicine. Int J Mol Sci. 2019;20(8):1820. https://doi. org/10.3390/ijms20081820

\section{PMid:31013779}

20. Yancy CW, Jessup M, Bozkurt B, Butler J, Casey DE Jr., Colvin MM, et al. 2017 ACC/AHA/HFSA focused update of the 2013 ACCF/AHA guideline for the management of heart failure: A report of the American college of cardiology/American heart association task force on clinical practice guidelines and the heart failure society of America. Circulation. 2017;136(6):e13761. https://doi.org/10.1161/cir.0000000000000460

\section{PMid:28455343}

21. Ponikowski $P$, Voors AA, Anker SD, Bueno $H$, Cleland JG Coats AJ, et al. 2016 ESC Guidelines for the diagnosis and treatment of acute and chronic heart failure: The task force for the diagnosis and treatment of acute and chronic heart failure of the European society of cardiology (ESC) developed with the special contribution of the heart failure association (HFA) of the ESC. Eur Heart J. 2016;37(27):2129-200. https://doi.org/10.341 O/f.718489795.793497182

PMid:27206819

22. Salah K, Stienen S, Pinto YM, Eurlings LW, Metra M, BayesGenis A, et al. Prognosis and NT-proBNP in heart failure patients with preserved versus reduced ejection fraction. Heart. 2019;105(15):1182-9. https://doi.org/10.1136/ heartjnl-2018-314173

PMid:30962192

23. Palazzuoli A, Beltrami M, Ruocco G, Franci B, Campagna MS, Nuti R. Diagnostic utility of contemporary echo and BNP assessment in patients with acute heart failure during early hospitalization. Eur J Intern Med. 2016;30:43-8. https://doi. org/10.1016/j.ejim.2015.11.031

\section{PMid:26718066}

24. Karakiliç E, Kepez A, Abali G, Coşkun F, Kunt M, Tokgözoğlu L. The relationship between B-type natriuretic peptide levels and echocardiographic parameters in patients with heart failure admitted to the emergency department. Anadolu Kardiyol Derg. 2010;10(2):143-9. https://doi.org/10.5152/akd.2010.040 PMid:20382614

25. Tschöpe C, Kasner M, Westermann D, Gaub R, Poller WC Schultheiss HP. The role of NT-proBNP in the diagnostics of isolated diastolic dysfunction: Correlation with echocardiographic and invasive measurements. Eur Heart J. 2005;26(21):2277-84 https://doi.org/10.1093/eurheartj/ehi406

PMid: 16014646

26. Afshani N, Moustaqim-Barrette A, Biccard BM, Rodseth RN, Dyer RA. Utility of B-type natriuretic peptides in preeclampsia: A systematic review. Int J Obstet Anesth. 2013;22(2):96-103. https://doi.org/10.1016/j.ijoa.2012.11.001 PMid:23462297

27. Alma LJ, Bokslag A, Maas AH, Franx A, Paulus WJ, de Groot CJ. Shared biomarkers between female diastolic heart failure and pre-eclampsia: A systematic review and meta-analysis. ESC Heart Fail. 2017;4(2):88-98. https://doi.org/10.1002/ehf2.12129 PMid:28451444

28. Szabó G, Molvarec A, Nagy B, Rigó J Jr. Increased B-type natriuretic peptide levels in early-onset versus late-onset preeclampsia. Clin Chem Lab Med. 2014;52(2):281-8. https:// doi.org/10.1515/cclm-2013-0307 PMid:23979127

29. Fayers S, Moodley J, Naidoo DP. Cardiovascular haemodynamics in pre-eclampsia using brain naturetic peptide and tissue Doppler studies. Cardiovasc J Afr. 2013;24(4):130-6. https://doi.org/10.5830/cvja-2013-023 PMid:24217044

30. Ghomian N, Vakilian F, Shahri B, Rostaminejad V, KhademRezaiyan M. Can brain natriuretic peptide predict cardiovascular complications in severe preeclampsia? A case-control study. Int J Reprod Biomed. 2019;17(4):271-8. https://doi.org/10.18502/ ijrm.v17i4.4552 PMid:31435608

31. Tihtonen KM, Kööbi T, Vuolteenaho O, Huhtala HS, Uotila JT. Natriuretic peptides and hemodynamics in preeclampsia. Am J Obstet Gynecol. 2007;196(4):328.e1-7. https://doi. org/10.1016/j.ajog.2006.11.033 PMid:17403408

32. Sadlecki P, Grabiec M, Walentowicz-Sadlecka M. Prenatal clinical assessment of NT-proBNP as a diagnostic tool for preeclampsia, gestational hypertension and gestational diabetes mellitus. PLoS One. 2016;11(9):e0162957. https://doi. org/10.1371/journal.pone.0162957 PMid:27685993

33. Thygesen K, Alpert JS, Jaffe AS, Chaitman BR, Bax JJ, Morrow DA, et al. Executive Group on behalf of the Joint European Society of Cardiology (ESC)/American College of Cardiology (ACC)/American Heart Association (AHA)/World Heart Federation (WHF) Task Force for the Universal Definition of Myocardial Infarction. Fourth Universal Definition of Myocardial Infarction (2018). Circulation. 2018 Nov 13;138(20):e618-e51.

34. Ottani F, Galvani M, Nicolini FA, Ferrini D, Pozzati A, Di Pasquale G, et al. Elevated cardiac troponin levels predict the risk of adverse outcome in patients with acute coronary syndromes. Am Heart J. 2000;140(6):917-27. https://doi. org/10.1067/mhj.2000.111107 PMid:11099996

35. Saunders JT, Nambi V, de Lemos JA, Chambless LE, Virani SS, Boerwinkle E, Hoogeveen RC, et al. Cardiac troponin $T$ 
measured by a highly sensitive assay predicts coronary heart disease, heart failure, and mortality in the atherosclerosis risk in communities study. Circulation. 2011;123(13):1367-76. https:// doi.org/10.1161/circulationaha.110.005264

\section{PMid:21422391}

36. Pergialiotis V, Prodromidou A, Frountzas $M$, Perrea DN, Papantoniou N. Maternal cardiac troponin levels in preeclampsia: A systematic review. J Matern Fetal Neonatal Med. 2016;29(20):3386-90. https://doi.org/10.3109/14767058.2015.1 127347

\section{PMid:26745550}

37. Fleming SM, O'Gorman T, Finn J, Grimes H, Daly K, Morrison JJ. Cardiac troponin I in pre-eclampsia and gestational hypertension. BJOG. 2000;107(11):1417-20. https://doi. org/10.1111/j.1471-0528.2000.tb11658.x

PMid:11117772

38. Morton A, Morton A. High sensitivity cardiac troponin I levels in preeclampsia. Pregnancy Hypertens. 2018;13:79-82. https:// doi.org/10.1016/j.preghy.2018.04.020

PMid:30177077

39. Ravichandran J, Woon SY, Quek YS, Lim YC, Noor EM, Suresh K, et al. High-sensitivity cardiac troponin I levels in normal and hypertensive pregnancy. Am J Med. 2019;132(3):362-6. https://doi.org/10.1016/j.amjmed.2018.11.017 PMid:30503877

40. Joyal D, Leya F, Koh M, Besinger R, Ramana R, Kahn S, et al. Troponin I levels in patients with preeclampsia. Am J Med. 2007;120(9):819.e13-4. https://doi.org/10.1016/j. amjmed.2006.05.068

\section{PMid:17765054}

41. Umazume T, Yamada S, Yamada T, Ishikawa S, Furuta I, Iwano $\mathrm{H}$, et al. Association of peripartum troponin I levels with left ventricular relaxation in women with hypertensive disorders of pregnancy. Open Heart. 2018;5(2):e000829. https://doi. org/10.1136/openhrt-2018-000829

PMid:30245837

42. Muijsers HE, Westermann D, Birukov A, van der Heijden OW, Drost JT, Kräker $\mathrm{K}$, et al. High-sensitivity cardiac troponin $\mathrm{I}$ in women with a history of early-onset preeclampsia. J Hypertens. 2020;38(10):1948-54. https://doi.org/10.1097/ hjh.0000000000002497

PMid:32890270

43. Homsak E, Gruson D. Soluble ST2: A complex and diverse role in several diseases. Clin Chim Acta. 2020;507:75-87. https:// doi.org/10.1016/j.cca.2020.04.011

PMid:32305537

44. Sanada S, Hakuno D, Higgins L, Schreiter ER, McKenzie AN, Lee RT. IL-33 and ST2 comprise a critical biomechanically induced and cardioprotective signaling system. J Clin Invest. 2007;117(6):1538-49. https://doi.org/10.1172/jci30634 PMid:17492053

45. Daniels LB, Clopton P, Iqbal N, Tran K, Maisel AS. Association of ST2 levels with cardiac structure and function and mortality in outpatients. Am Heart J. 2010;160(4):721-8. https://doi. org/10.1016/j.ahj.2010.06.033

PMid:20934567

46. Pratama RS, Hartopo AB, Anggrahini DW, Dewanto VC, Dinarti LK. Serum soluble suppression of tumorigenicity-2 level associates with severity of pulmonary hypertension associated with uncorrected atrial septal defect. Pulm Circ. 2020;10(2):2045894020915832. https://doi. org/10.1177/2045894020915832 PMid:32518620

47. Zhang Y, Fan Z, Liu H, Ma J, Zhang M. Correlation of plasma soluble suppression of tumorigenicity-2 level with the severity and stability of coronary atherosclerosis. Coron Artery Dis. 2020;31(7):628-35. https://doi.org/10.1097/ mca.0000000000000851 PMid:32040025

48. Gaggin HK, Szymonifka J, Bhardwaj A, Belcher A, De Berardinis B, Motiwala S, et al. Head-to-head comparison of serial soluble ST2, growth differentiation factor-15, and highlysensitive troponin $\mathrm{T}$ measurements in patients with chronic heart failure. JACC Heart Fail. 2014;2(1):65-72. https://doi. org/10.1016/j.jchf.2013.10.005

PMid:24622120

49. AbouEzzeddine OF, McKie PM, Dunlay SM, Stevens SR, Felker GM, Borlaug BA, et al. Suppression of tumorigenicity 2 in heart failure with preserved ejection fraction. J Am Heart Assoc. 2017;6(2):e004382. https://doi.org/10.1161/jaha.116.004382 PMid:28214792

50. Romero R, Chaemsaithong P, Tarca AL, Korzeniewski SJ, Maymon E, Pacora P, et al. Maternal plasma-soluble ST2 concentrations are elevated prior to the development of early and late onset preeclampsia-a longitudinal study. J Matern Fetal Neonatal Med. 2018;31(4):418-32. https://doi.org/10.1080/1476 7058.2017.1286319

PMid:28114842

51. Stampalija $T$, Chaiworapongsa $T$, Romero R, Chaemsaithong $P$, Korzeniewski SJ, Schwartz AG, et al. Maternal plasma concentrations of SST2 and angiogenic/anti-angiogenic factors in preeclampsia. J Matern Fetal Neonatal Med. 2013;26(14):1359-70. https://doi.org/10.3109/14767058.2013.7 84256

PMid:23488689

52. Mugerli S, Ambrožič J, Geršak K, Lučovnik M. Elevated soluble-ST2 concentrations in preeclampsia correlate with echocardiographic parameters of diastolic dysfunction and return to normal values one year after delivery. J Matern Fetal Neonatal Med. 2021;34(3):379-85. https://doi.org/10.1080/1476 7058.2019.1609934

PMid:31056999

53. de Boer RA, Voors AA, Muntendam P, van Gilst WH, van Veldhuisen DJ. Galectin-3: A novel mediator of heart failure development and progression. Eur $\mathrm{J}$ Heart Fail. 2009;11(9):811-7. https://doi.org/10.1093/eurjhf/hfp097 PMid: 19648160

54. Frunza O, Russo I, Saxena A, Shinde AV, Humeres C, Hanif W, et al. Myocardial galectin-3 expression is associated with remodeling of the pressure-overloaded heart and may delay the hypertrophic response without affecting survival, dysfunction, and cardiac fibrosis. Am J Pathol. 2016;186(5):1114-27. https:// doi.org/10.1016/j.ajpath.2015.12.017

PMid:26948424

55. Sharma UC, Pokharel S, van BrakelTJ, van Berlo JH, Cleutjens JP, Schroen B, et al. Galectin-3 marks activated macrophages in failure-prone hypertrophied hearts and contributes to cardiac dysfunction. Circulation. 2004;110(19):3121-8. https://doi. org/10.1161/01.cir.0000147181.65298.4d PMid:15520318

56. Meijers WC, Januzzi JL, deFilippi C, Adourian AS, Shah SJ, van Veldhuisen DJ, et al. Elevated plasma galectin-3 is associated with near-term rehospitalization in heart failure: A pooled analysis of 3 clinical trials. Am Heart J. 2014;167(6):853-60.e4. https://doi.org/10.1016/j.ahj.2014.02.011

PMid:24890535

57. Mazurek JA, Horne BD, Saeed W, Sardar MR, Zolty R. Galectin-3 levels are elevated and predictive of mortality in pulmonary hypertension. Heart Lung Circ. 2017;26(11):1208-15. https:// doi.org/10.1016/j.hlc.2016.12.012 


\section{PMid:28242288}

58. Nar G, Aksan G, Gorgulu O, Inci S, Soylu K, Ozdemir M, et al Galectin-3 as a novel biomarker for the diagnosis of essential hypertension with left ventricular hypertrophy. J Exp Clin Med. 2016;33:123-8.

59. Zaborska B, Sygitowicz G, Smarż K, Pilichowska-Paszkiet E, Budaj A. Galectin-3 is related to right ventricular dysfunction in heart failure patients with reduced ejection fraction and may affect exercise capacity. Sci Rep. 2020;10(1):16682. https://doi. org/10.1038/s41598-020-73634-8 PMid:33028850

60. Taha AS, Zahraei Z, Al-Hakeim H. Serum apelin and galectin-3 in preeclampsia in Iraq. Preprints. 2019;2019:100270. https:// doi.org/10.20944/preprints201910.0270.v1

61. Jeschke U, Mayr D, Schiessl B, Mylonas I, Schulze S, Kuhn C, et al. Expression of galectin-1, -3 (gal-1, gal-3) and the ThomsenFriedenreich (TF) antigen in normal, IUGR, preeclamptic and HELLP placentas. Placenta. 2007;28(11-12):1165-73. https:// doi.org/10.1016/j.placenta.2007.06.006

62. Demmert M, Faust K, Bohlmann MK, Tröger B, Göpel W, Herting $E$, et al. Galectin-3 in cord blood of term and preterm infants. Clin Exp Immunol. 2012;167(2):246-51. https://doi. org/10.1111/j.1365-2249.2011.04509.x

PMid:22236000

63. Breit SN, Johnen $H$, Cook AD, Tsai VW, Mohammad ME, Kuffner T, et al. The TGF- $\beta$ superfamily cytokine, MIC-1/GDF15: A pleotrophic cytokine with roles in inflammation, cancer and metabolism. Growth Factors. 2011;29(5):187-95. https://doi.org /10.3109/08977194.2011.607137 PMid:21831009

64. Kempf T, Eden M, Strelau J, Naguib M, Willenbockel C, Tongers $\mathrm{J}$, et al. The transforming growth factor-beta superfamily member growth-differentiation factor-15 protects the heart from ischemia/reperfusion injury. Circ Res. 2006;98(3):351-60. https://doi.org/10.1161/01.res.0000202805.73038.48 PMid:16397141

65. Schlittenhardt D, Schober A, Strelau J, Bonaterra GA, Schmiedt W, Unsicker $\mathrm{K}$, et al. Involvement of growth differentiation factor-15/macrophage inhibitory cytokine-1 (GDF-15/MIC-1) in oxLDL-induced apoptosis of human macrophages in vitro and in arteriosclerotic lesions. Cell Tissue Res. 2004;318(2):325-33. https://doi.org/10.1007/ s00441-004-0986-3

PMid: 15459768

66. Anand IS, Kempf T, Rector TS, Tapken H, Allhoff T, Jantzen F, et al. Serial measurement of growth-differentiation factor-15 in heart failure: Relation to disease severity and prognosis in the valsartan heart failure trial. Circulation. 2010;122(14):1387-95. https://doi.org/10.1161/circulationaha.109.928846

PMid:20855664

67. Kempf T, Horn-Wichmann R, Brabant G, Peter T, Allhoff T, Klein G et al. Circulating concentrations of growth-differentiation factor 15 in apparently healthy elderly individuals and patients with chronic heart failure as assessed by a new immunoradiometric sandwich assay. Clin Chem. 2007;53(2):284-91. https://doi. org/10.1373/clinchem.2006.076828

PMid: 17185363

68. Chen Q, Wang Y, Zhao M, Hyett J, da Silva Costa F, Nie G. Serum levels of GDF15 are reduced in preeclampsia and the reduction is more profound in late-onset than early-onset cases. Cytokine. 2016;83:226-30. https://doi.org/10.1016/j. cyto.2016.05.002

PMid:27173615

69. Sugulle $M$, Dechend $R$, Herse $F$, Weedon-Fekjaer MS, Johnsen GM, Brosnihan $\mathrm{KB}$, et al. Circulating and placental growth-differentiation factor 15 in preeclampsia and in pregnancy complicated by diabetes mellitus. Hypertension. 2009;54(1):106-12. https://doi.org/10.1161/ hypertensionaha.109.130583

PMid:19470878

70. Yuksel TI, Mathyk BA, Cetin BA, Turhan U, Okumus ZG, Yildirim GY, et al. Maternal levels of growth differentiation factor-15 in patients with preeclampsia. Hypertens Pregnancy. 2018;37(4):192-6. https://doi.org/10.1080/10641955.201 8.1524477

PMid:30295110 